\title{
Osteology and relationships of Rhinopycnodus gabriellae gen. et sp. nov. (Pycnodontiformes) from the marine Late Cretaceous of Lebanon
}

\author{
Louis TAVERNE ${ }^{1,3} \&$ Luigi CAPASSO ${ }^{2,4}$ \\ ${ }^{1}$ Royal Belgian Institute of Natural Sciences, Department of Paleontology, Vautierstreet 29, B-1000 \\ Brussels, Belgium. E-mail: louis.taverne@gmail.com \\ ${ }^{2}$ Museo Universitario dell’Universitá "G. d'Annunzio" di Chieti-Pescara, Piazza Trento e Trieste 1, \\ I-661000 Chieti, Italy. E-mail: 1capasso@unich.it \\ ${ }^{3}$ urn:Isid:zoobank.org:author:0CF81641-1DD1-4CBD-9735-F1FE7EB0BCF5 \\ ${ }^{4}$ urn:Isid:zoobank.org:author:C79C14CF-C1D7-48E3-9BA9-CAD8AA0909F7
}

\begin{abstract}
The osteology of Rhinopycnodus gabriellae gen. and sp. nov., a pycnodontiform fish from the marine Cenomanian (Late Cretaceous) of Lebanon, is studied in detail. This new fossil genus belongs to the family Pycnodontidae, as shown by the presence of a posterior brush-like process on its parietal. Its long and broad premaxilla, bearing one short and very broad tooth is the principal autapomorphy of this fish. Within the phylogeny of Pycnodontidae, Rhinopycnodus occupies an intermediate position between Ocloedus and Tepexichthys.
\end{abstract}

Key words. Pycnodontidae, Rhinopycnodus gabriellae gen. et sp. nov., osteology, relationships, Cretaceous, Lebanon.

Taverne L. \& Capasso L. 2013, Osteology and relationships of Rhinopycnodus gabriellae gen. et sp. nov. (Pycnodontiformes) from the marine Late Cretaceous of Lebanon. European Journal of Taxonomy 67: 1-14. http:// dx.doi.org/10.5852/ejt.2013.67

\section{Introduction}

Pycnodont fossil fishes are by far the largest group within Halecostomi (about 40 genera and more than 650 nominal species). They lived from the Late Triassic to the Middle Eocene and reached a nearly worldwide distribution during the Late Cretaceous (Nursall 1996a; Kriwet 2001). They were mostly marine fishes, generally having a deep and laterally compressed body. Their mode of feeding was durophagous, as can be deducted from the molariform teeth on the vomer and the prearticulars (Nursall 1996a: fig. 3). They are considered as closely related to the teleosts (Nursall 2010). Formerly all pycnodont fishes were grouped in one order, the Pycnodontiformes (Nursall 1996b; Poyato-Ariza \& Wenz 2002; Kriwet 2005). They are now ranged in a new superorder Pycnodontomorpha, comprising two orders, the Gyrodontiformes and the Pycnodontiformes [new usage for the former Pycnodontoidei] (Nursall 2010).The aim of our paper is to describe a new pycnodontiform genus from the marine Upper Cenomanian of Haqel, Lebanon and to determine its systematic position within the order. 


\section{Material and methods}

The holotype of the new pycnodontiform genus belongs to the Luigi Capasso collection (CLC) in Chieti (Italy), that is legally registered by a decree of the Ministero per i Beni e le Attività Culturali under the date of October $11^{\text {th }}, 1999$, following the disposition of the Italian law 1089/39. The Soprintendenza per i Beni Archeologici dell'Abruzzo - Chieti has authorized the authors to study this collection by a letter bearing the date of May 5 ${ }^{\text {th }}, 2011$ (reference: MBAC-SBA-ABR PROT 0004537 05/05/2011 Cl. 34.25.01/2.1).

This sample was studied with a Leica-Wild M8 stereo microscope. The drawings of the figures were made by the first author. Aspersions with ethanol were used to improve the observations.

\section{List of abbreviations used in text and figures}

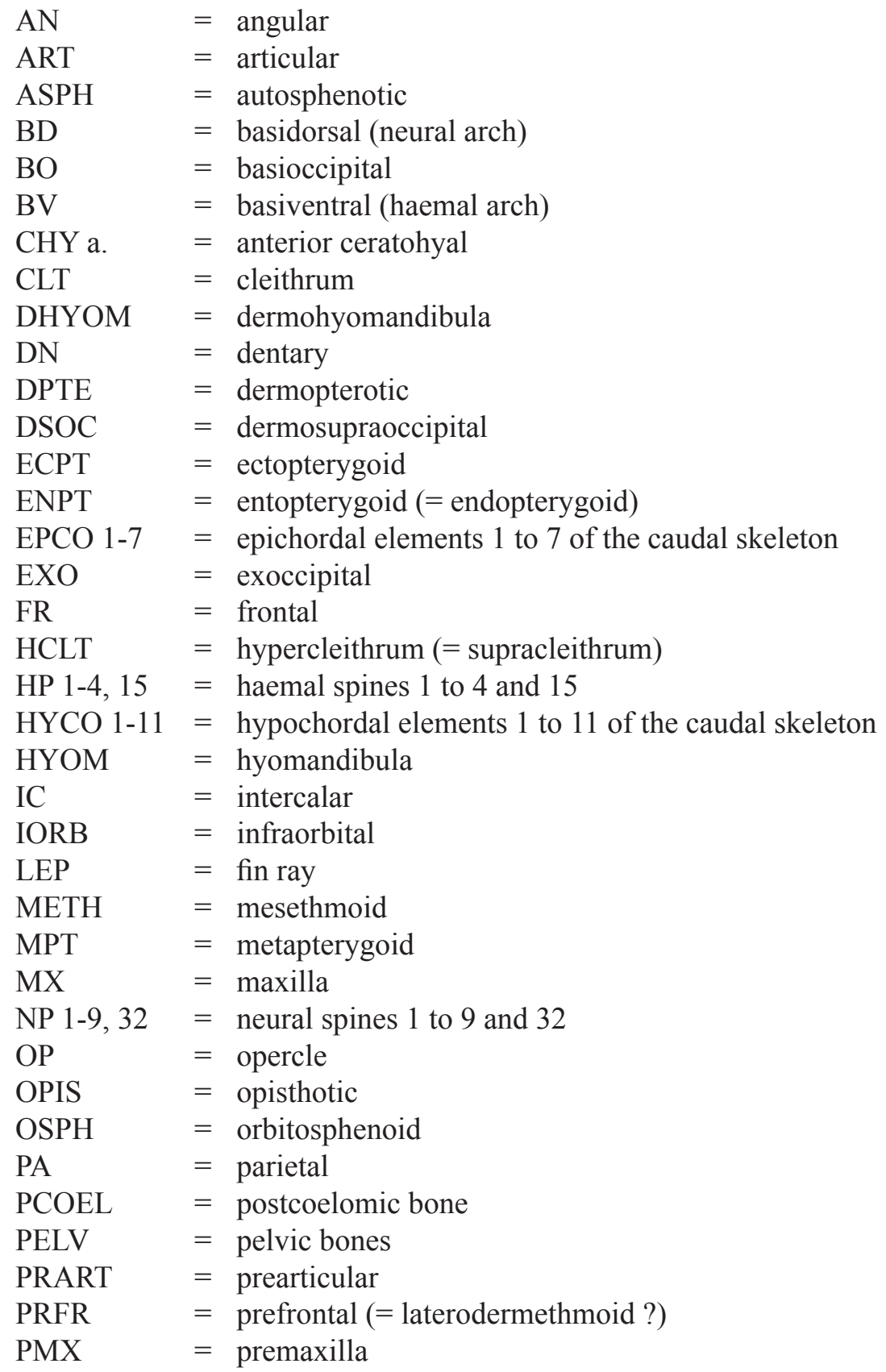


TAVERNE L. \& CAPASSO L., A new pycnodontiform fish from the Cretaceous of Lebanon

$\begin{array}{ll}\text { POP } & =\text { preopercle } \\ \text { PRART } & =\text { prearticular } \\ \text { PRFR } & =\text { prefrontal } \\ \text { PS } & =\text { parasphenoid } \\ \text { PT } & =\text { posttemporal } \\ \text { QU } & =\text { quadrate } \\ \text { RAD } & =\text { pterygiophores (= radials) } \\ \text { RAD 1-4 } & =\text { first four anal pterygiophores } \\ \text { SC } & =\text { scale } \\ \text { SC b. } & =\text { scale bar } \\ \text { SC d. 1-12 } & =\text { first twelve scales of the dorsal ridge } \\ \text { SC 1. 1. 1 } & =\text { first scale of the lateral line } \\ \text { SC pel. 1-3 } & =\text { pelvic scales 1-3 } \\ \text { SC pocl. 1-2 } & =\text { postcloacal scales 1-2 } \\ \text { SC v. } & =\text { scales of the ventral keel } \\ \text { SL } & =\text { standard length } \\ \text { SY } & =\text { symplectic } \\ \text { UD } & =\text { urodermal } \\ \text { VO } & =\text { vomer }\end{array}$

\section{Results}

Systematic paleontology

Subclass Actinopterygii Klein, 1885

Series Neopterygii Regan, 1923

Division Halecostomi Regan, 1923 sensu Patterson 1973

Superorder Pycnodontomorpha Nursall, 2010

Order Pycnodontiformes Berg, 1937 sensu Nursall 2010

Family Pycnodontidae Agassiz, 1833

Genus Rhinopycnodus gen. nov.

urn:1sid:zoobank.org:act:61F4FDD2-68EC-49EE-B7AB-F36120047FDB

\section{Type-species}

Rhinopycnodus gabriellae gen. et sp. nov. (by monotypy)

\section{Diagnosis}

As for the species (monospecific genus).

\section{Etymology}

From the Greek ris, rinos, the nose. Indeed, the upper jaw of the fish looks like a hog snout when seen in profile. The generic name Pycnodus is added.

Rhinopycnodus gabriellae gen. et sp. nov.

Figs 1-8

urn:1sid:zoobank.org:act:D5399E6C-45DF-4D7D-BA77-545D6014BE22

\section{Diagnosis}

Primitive pycnodontid characterized by a long and broad premaxilla bearing one short and very broad tooth. Elongated head with a long preorbital region. Dentary bearing 2 small incisiform teeth. No 


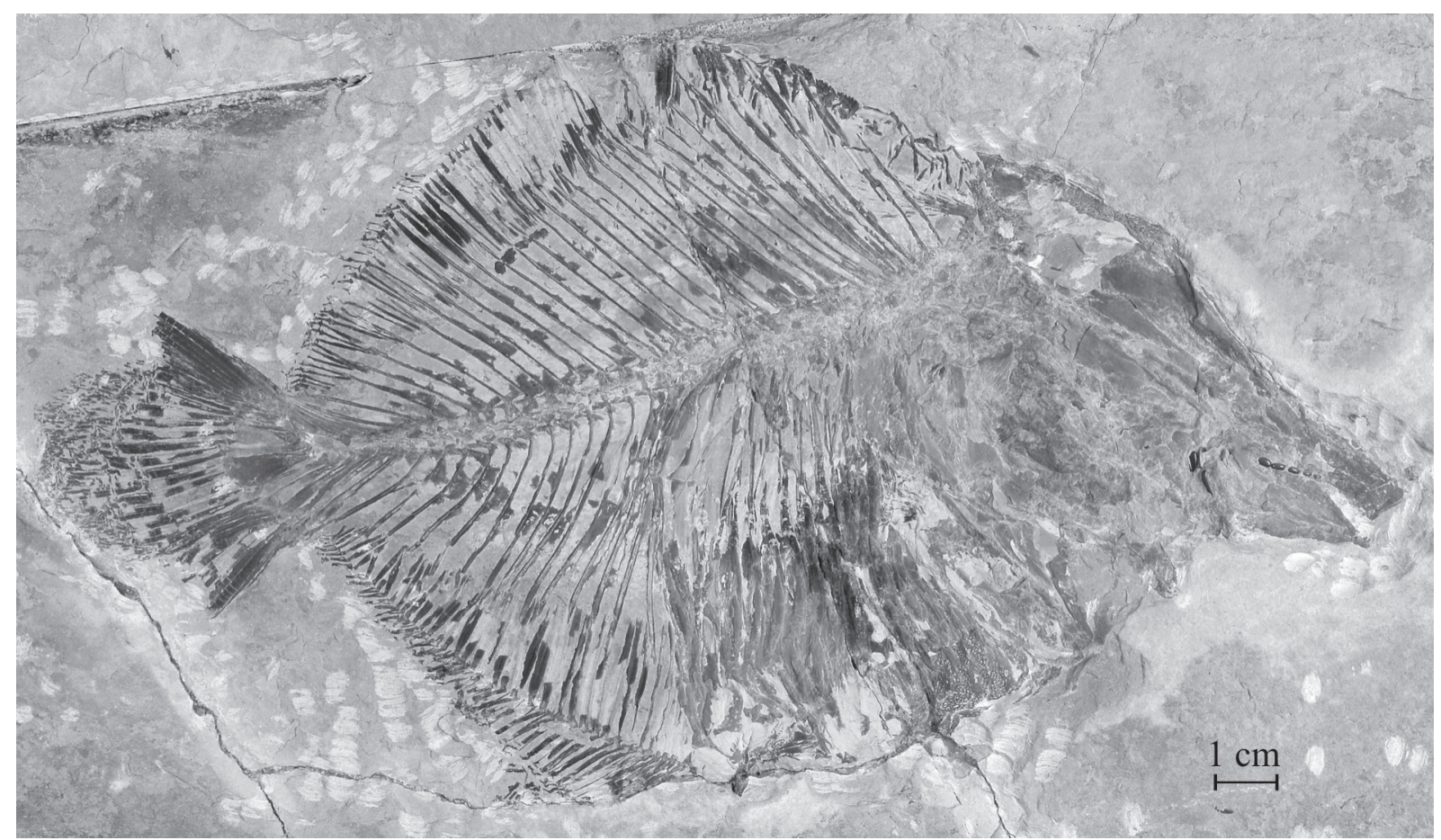

Fig. 1. Rhinopycnodus gabriellae gen. et sp. nov. Holotype CLC S-725.

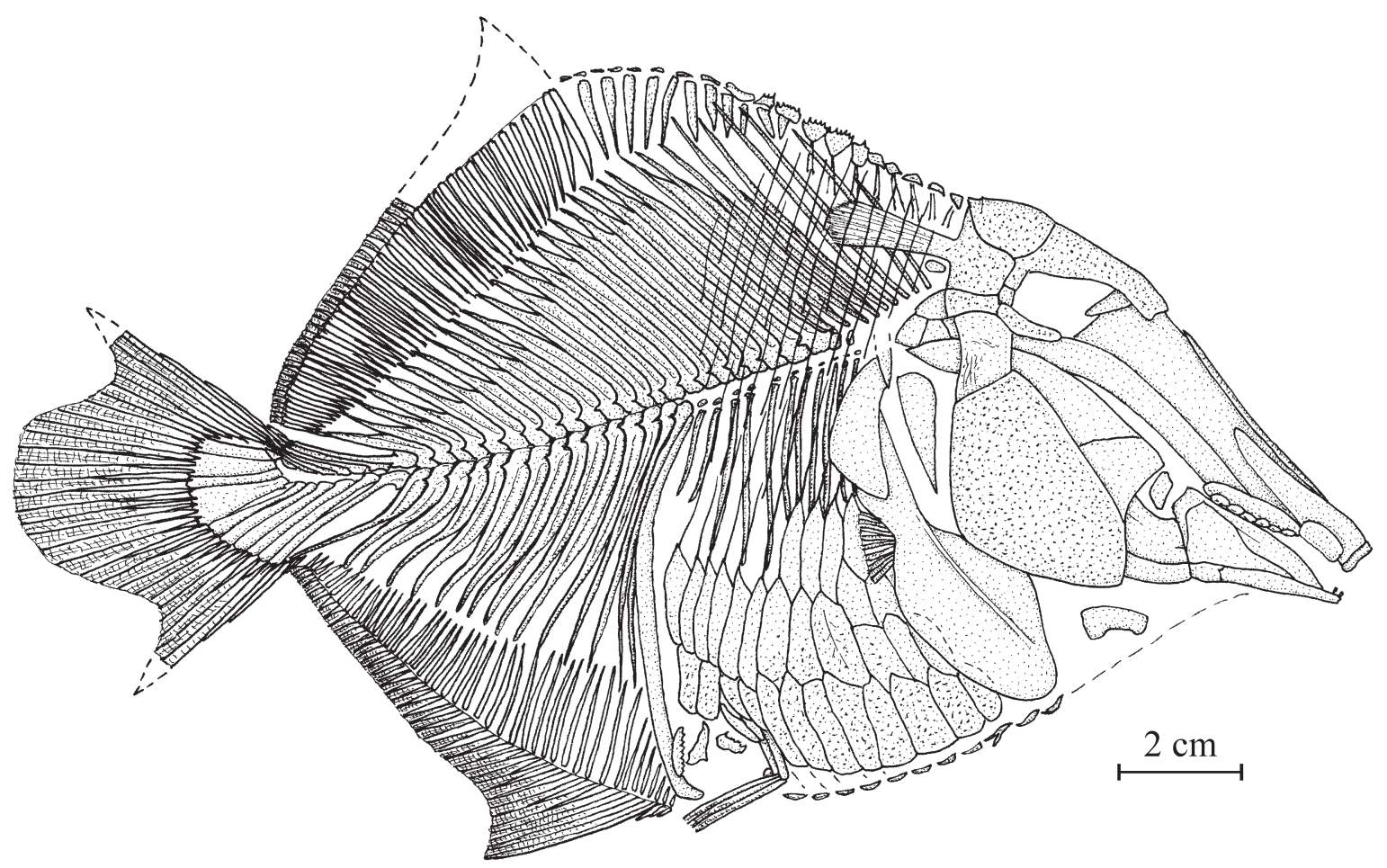

Fig. 2. Rhinopycnodus gabriellae gen. et sp. nov. Reconstruction of holotype CLC S-725. 
TAVERNE L. \& CAPASSO L., A new pycnodontiform fish from the Cretaceous of Lebanon

temporal fossa. Exoccipital-basioccipital region well visible behind the dermopterotic. Mouth gape obliquely oriented. Preopercle larger than the exposed region of the hyomandibula-dermohyomandibula. Maximum body depth: $67.6 \%$ of the SL. Pectoral fin with 9 rays. Ventral fin with 3 rays. Dorsal fin with 49 pterygiophores. Origin of the dorsal fin behind the dorsal apex and at $76.2 \%$ of the SL. Anal fin with 47 rays and 45 pterygiophores. Origin of the anal fin on the ventral apex and at $63.8 \%$ of the SL. Neural and haemal arches almost completely surrounding the notochord. 32 vertebral elements (neural spines) before the epichordal series. Neural spines 1-8 autogenous. 11 pairs of ribs. Postcoelomic bone reaching the axial skeleton and the ventral margin. 15 haemal spines before the hypochordal series. 7 epichordal and 11 hypochordal elements in the caudal skeleton. Caudal fin with 30 principal rays. Body scales only in the abdominal region. Complete scales ventrally and scale bars dorsally. 19 dorsal ridge scales. First dorsal ridge scale small, triangular in shape and not sutured to the dermosupraoccipital. Some spiny scales in the dorsal ridge and in the ventral keel. 3 pelvic scales. 2 postcloacal scales.

\section{Etymology}

The species name of the new Lebanese fossil fish is dedicated to Mrs. Gabriella di Tota, the co-author's wife.

\section{Formation and locality}

Marine Upper Cenomanian, Haqel, Lebanon.

\section{Holotype and unique specimen}

Sample CLC S-725, a complete specimen seen by its right side (Figs 1, 2) from Haqel, Lebanon. Total length: $223 \mathrm{~mm}$.

\section{Holotype morphometric data}

The morphometric data are given in \% of the standard length $(183 \mathrm{~mm})$ of the holotype.

Length of the head (opercle included) $45.2 \%$

Depth of the head (in the occipital region) $36.7 \%$

Maximum depth of the body (at the anal fin origin level) $67.6 \%$

Prepelvic length $52.4 \%$

Predorsal length $.76 .2 \%$

Basal length of the dorsal fin $39.0 \%$

Preanal length $63.8 \%$

Basal length of the anal fin $40.0 \%$

\section{Osteology}

\section{The skull (Figs 3, 4)}

The head is high, with the preorbital region much longer than the orbital-postorbital region. The dermal bones of the skull are slightly ornamented with small granulations. The mouth gape is inclined ventrally.

The mesethmoid is broad, very long and its upper margin is covered by a pair of long and very narrow prefrontals. The vomer is seen in profile and only six rounded molariform teeth ranged in one rank are visible. The frontal is rather short and not very broad. The posterior margin of the bone is a little enlarged and meets the dermosupraocciptal, the parietal and the small autosphenotic, but not the dermopterotic. Posteriorly, the dermosupraoccipital ends in a short pointed tip. The parietal bears a large posterior brush-like process. There is no temporal fenestra. The dermopterotic is not deepened and is located at the level of the upper border of the orbit. The opisthotic, intercalar, basioccipital and exoccipital are visible behind the dermopterotic and the hyomandibula. A small orbitosphenoid is pressed against the 
posterior border of the mesethmoid. The parasphenoid is very long and its trabecular region is obliquely oriented. Posteriorly, the parasphenoid reaches the level of the basioccipital. The sensory canals on the braincase are not visible.

The quadratic arch contains a well developed quadrate, a large metapterygoid, a large entopterygoid and a small ectopterygoid. The quadrate and the symplectic are both articulated on the lower jaw.

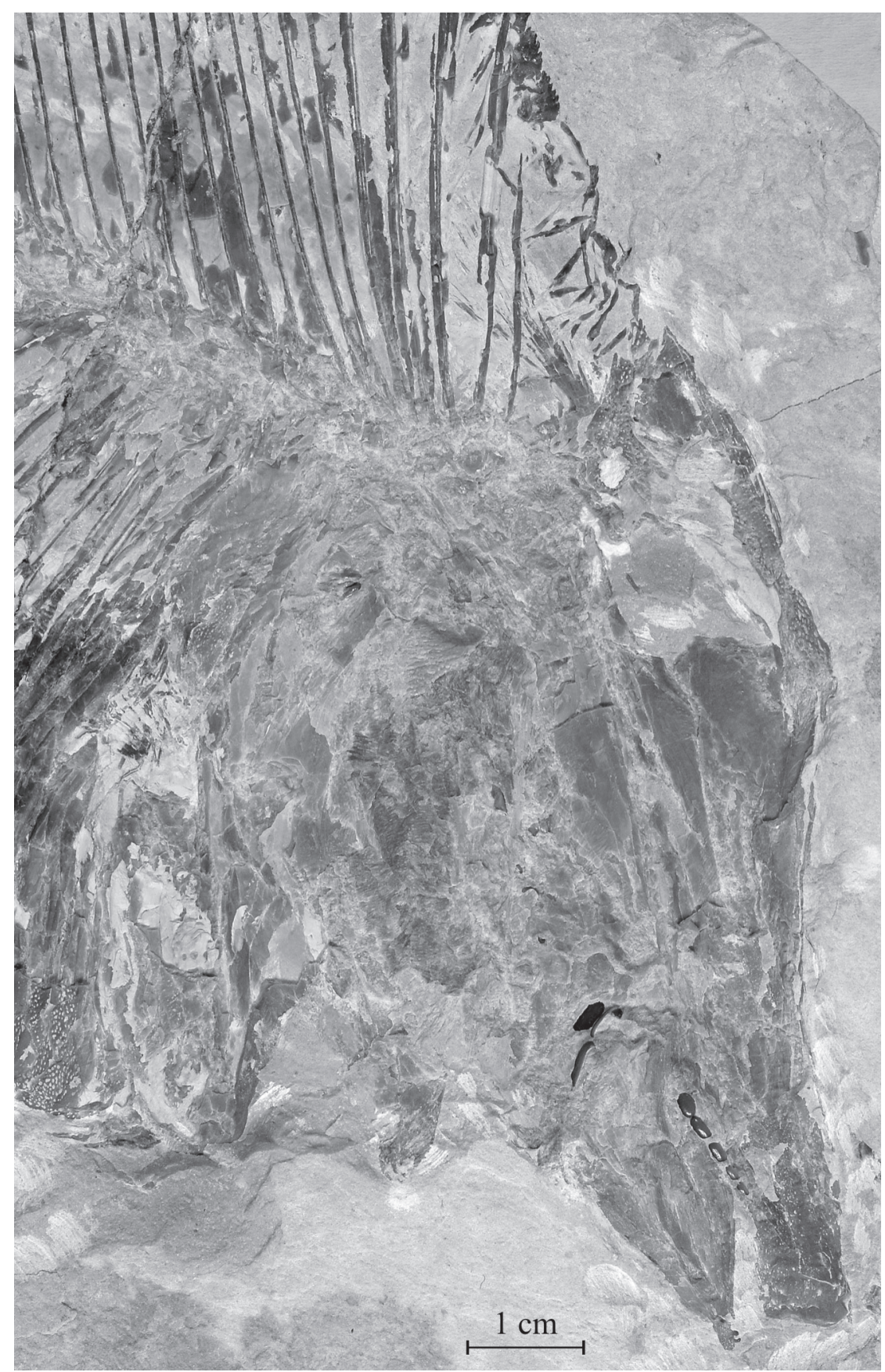

Fig. 3. Rhinopycnodus gabriellae gen. et sp. nov. Head and shoulder girdle region of holotype CLC S-725. 
The premaxilla is long and very broad. It bears only one short but very broad tooth. The maxilla is small, deeper than long, reniform, toothless and pressed against the premaxilla by its upper margin. When seen in profile, the upper jaw is hog snout-like because of the broadening of the premaxilla and of its tooth. The lower jaw is small and triangular in shape. The dentary is reduced to its ventral branch and it bears two small incisiform teeth. The angular covers a great part of the external face of the mandible. The small articular and the dentary are articulated together. The coronoid process of the prearticular is well marked. Three deep molariform teeth fallen from the prearticular are visible just behind the jaw.

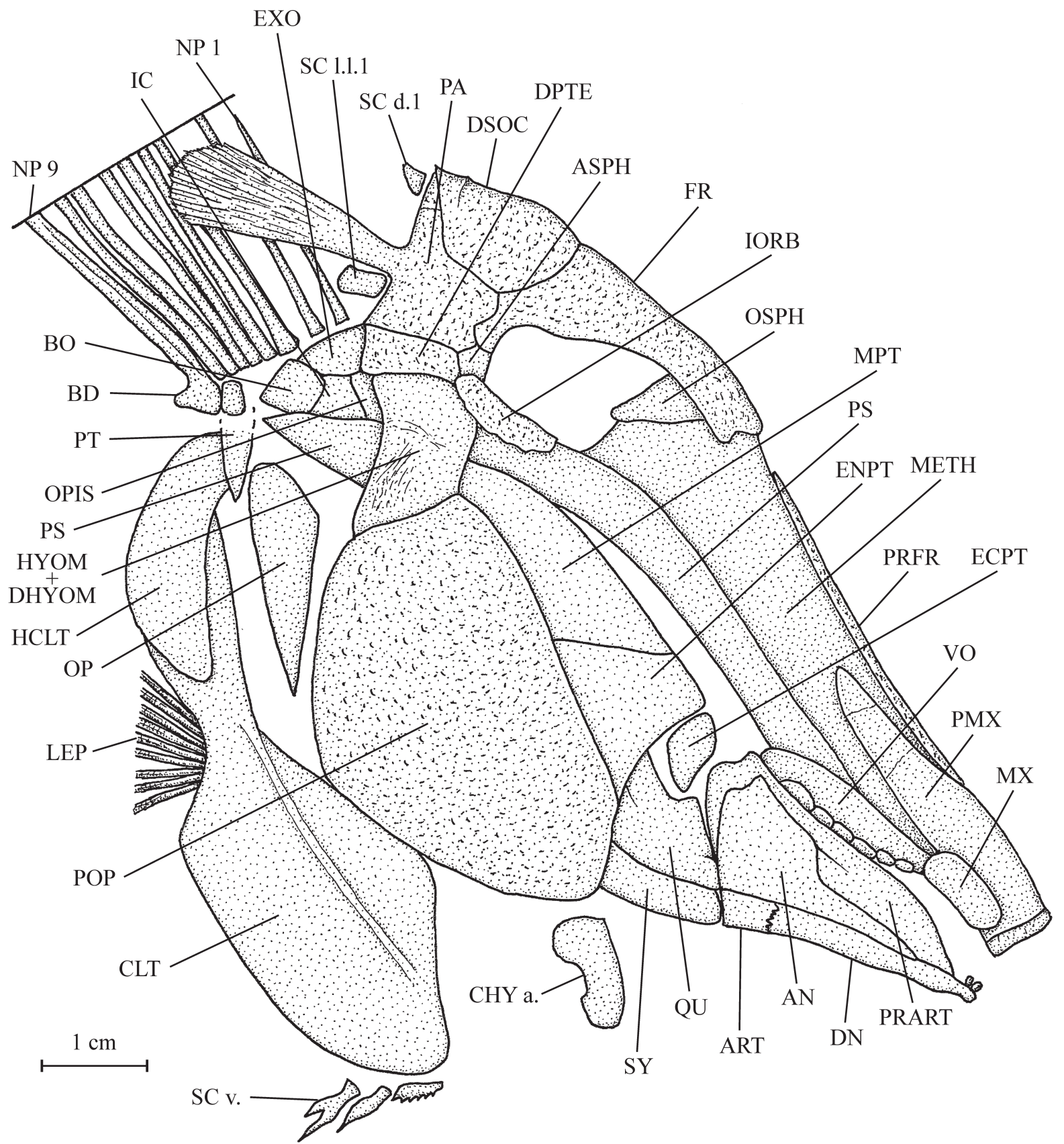

Fig. 4. Rhinopycnodus gabriellae gen. et sp. nov. Reconstruction of the skull and shoulder girdle of holotype CLC S-725. 
The last infraorbital is long, well ossified and forms the posterior and ventral margins of the orbit. No other infraorbital is preserved. The dermosphenotic is lost.

The preopercle is the largest bone of the skull, all together deep and broad. The hyomandibula and dermohyomandibula are fused and their exposed part is important but, however, much smaller than the preopercle. The opercle is well developed, with a pointed ventral tip and a broader upper part. No branchiostegal ray is preserved.

The anterior ceratohyal is the only preserved part of the hyoid bar. A few hook-like branchial teeth and some branchial filaments are visible under some broken regions of the opercle and preopercle.

\section{The girdles (Figs 3-5)}

Only the ventral part of the posttemporal is preserved. The hypercleithrum (= supracleithrum) is deep, rather broad and not splint-like as usual in Pycnodontiformes. The cleithrum is a large bone with a broad palaform ventral branch and a sinus in its posterior margin to house the pectoral fin, which is short and contains a least 9 rays.

The two pelvic bones are vertically oriented. The ventral fins are rather long. Each of them contains 3 rays. The origin of the ventral fins is located a little before the midpoint of the ventral contour.

\section{The axial skeleton (Fig. 2)}

Starting from the caudal region, the vertebral axis progressively elevates to reach the level of the orbit anteriorly. The vertebrae are constituted by only the dorsal and ventral arcocentra. No chordacentrum or autocentrum is visible. The neural and haemal arches surround the notochord almost completely. There are 32 neural spines before the epichordal series and thus 32 vertebral segments before the elements involved in the caudal fin support. The first 17 vertebral segments are abdominal and the following 15 caudal. The anteriormost 8 neural spines are autogenous. The first seven lean on the occipital region of the braincase and the eighth spine is located just above the first ossified but small basidorsal. The basiventrals are strongly reduced in the abdominal region but well developed in the caudal region. There are 11 pairs of long alate ribs and 15 haemal spines before the hypochordal series. The two last pairs of ribs are noticeably shorter than the nine preceding ribs. The first three haemal spines are pressed together and against the postcoelomic bone. The first haemal spine is incomplete and does not reach the axial skeleton. The neural and haemal spines bear an anterior sagittal flange, except for the first five neural and

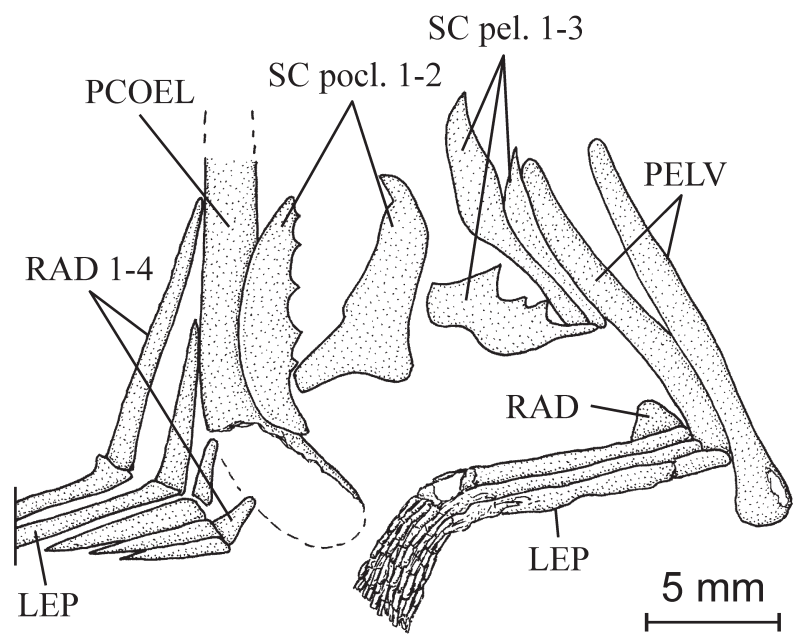

Fig. 5. Rhinopycnodus gabriellae gen. et sp. nov. Pelvic girdle of holotype CLC S-725, surrounding pelvic and postcloacal scales and beginning of the anal fin. 
the first three haemal spines. A well developed postzygaphophysis links each neural and haemal arch with the following one. The postcoelomic bone is a long and robust bone dorsally reaching the axial skeleton and ventrally the lower margin of the abdomen.

\section{The dorsal and anal fins (Fig. 2)}

The dorsal fin begins a little behind the dorsal apex. The fin is supported by 49 long and strong pterygiophores. The first seventeen of them have lost the corresponding rays. The last thirty two pterygiophores bear short segmented and branched rays. The first two pterygiophores are broader than the following ones.

The anal fin is strip-like in shape (type A2 of Poyato-Ariza \& Wenz 2002: fig. 34). The origin of the fin is located at the ventral apex. There are 45 strong pterygiophores bearing 47 rays. The first five pterygiophores abut against the postcoelomic bone and are progressively lengthened from the first to the fifth. The first three rays are reduced to short spines. The other rays are segmented and branched. The very short first pterygiophore supports two little spiny rays and the last pterygiophore two soft rays.

\section{The caudal skeleton (Figs 6,7 )}

There is no caudal peduncle because the dorsal and anal fins reach the caudal fin. The caudal endoskeleton contains 1 urodermal, 7 epichordal and 11 hypochordal elements. The first epichordal neural arch bears a long and narrow neural spine but the length of the neural spines progressively decreases from the first to the seventh epichordal element, which has only a very short neural spine. Some elements in the hypochordal series are broadened but there is no real hypertrophy. This broadening is more important on the eighth and the tenth hypochordal elements than on the other parts of the series.

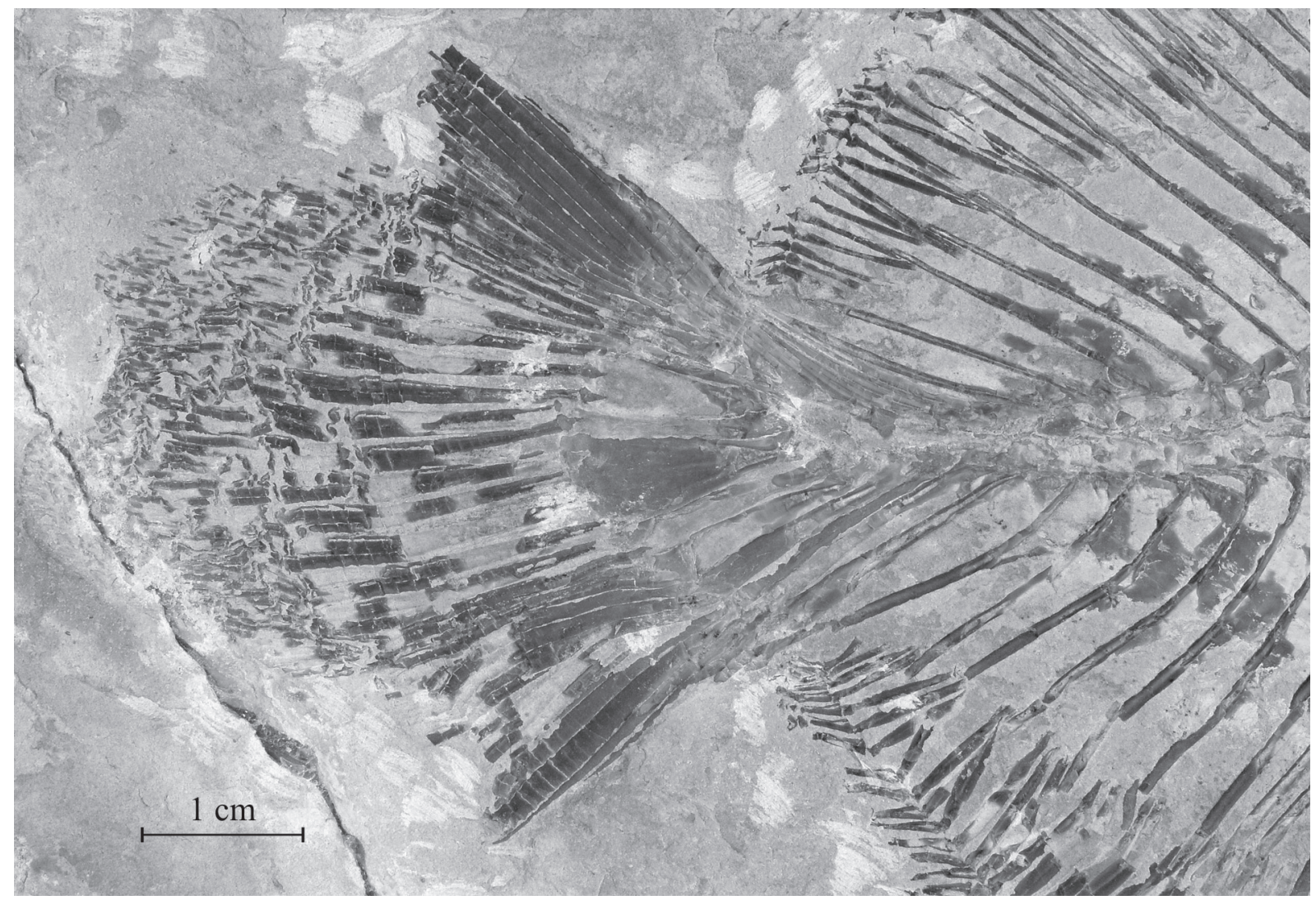

Fig. 6. Rhinopycnodus gabriellae gen. et sp. nov. Caudal region of holotype CLC S-725. 
The contour of the caudal fin is double emarginated (Poyato-Ariza \& Wenz 2002: fig. 36 E) but the median convex part of the fin is greatly enlarged. There are 30 principal rays, 3 dorsal and 4 ventral procurrent rays.

\section{Squamation (Figs 2, 4, 5, 8)}

The dorsal ridge and ventral keel scales are notably differentiated from the flank scales.

There are 19 dorsal ridge scales between the dermosupraoccipital and the origin of the dorsal fin but only the first and the seventh to the tenth are well preserved. The first dorsal scale is small, triangular in shape and located just behind the dermosupraoccipital. The five following scales are badly crushed. Only fragments of the last nine are visible in a fissure of the substratum at the dorsal apex level. Each upper margin of the seventh to tenth dorsal scales bears up to six small spines.

The total number of ventral ke el scales is unknown. The ventral keel begins with 3 scales located under the cleithrum (Fig. 4). The first one bears a few very small spines. The second one has a large spine and the third one two large spines. A few ventral keel scales bearing very small spines are visible on the

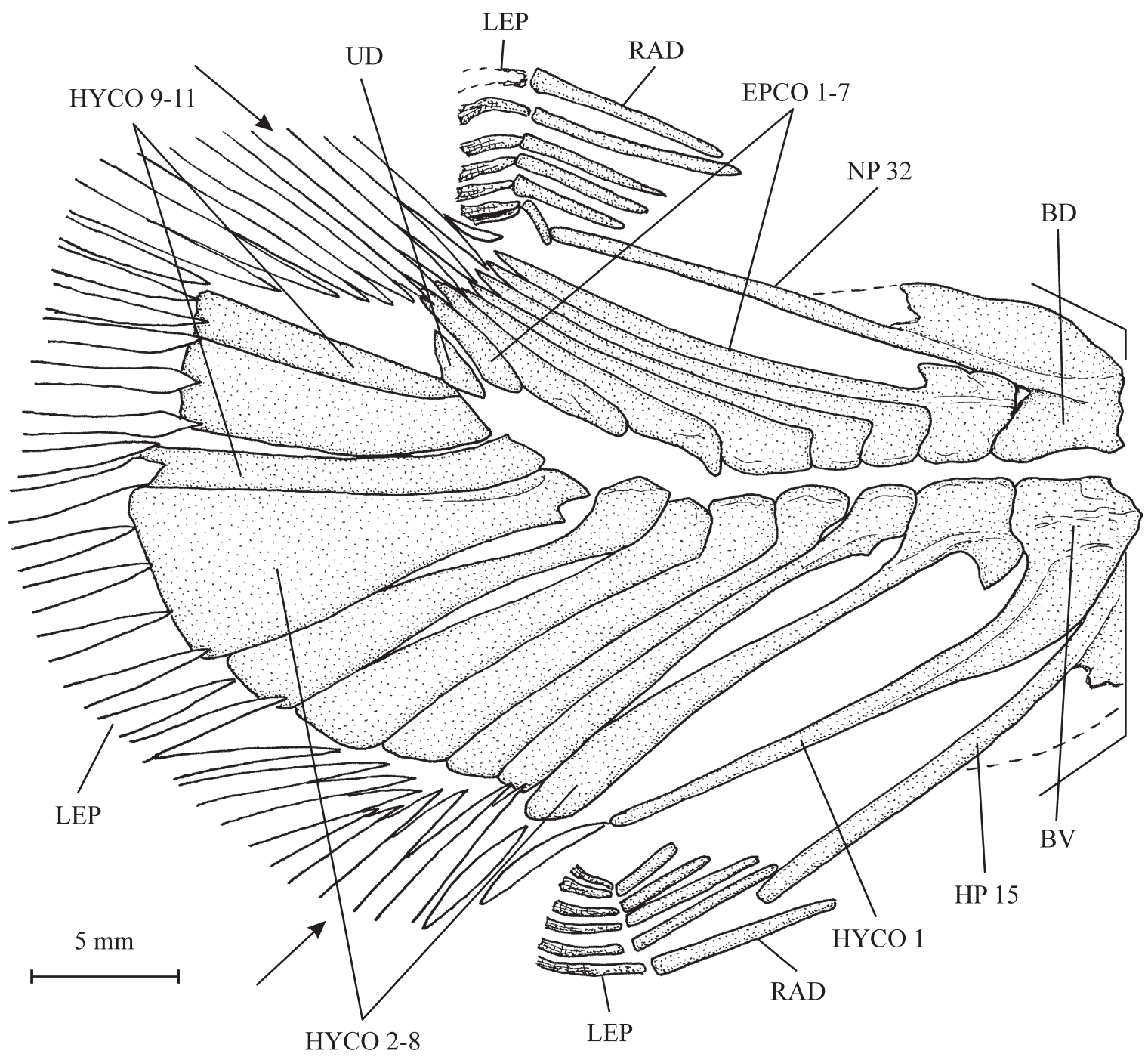

Fig. 7. Rhinopycnodus gabriellae gen. et sp. nov. Caudal skeleton of holotype CLC S-725. The arrows point at the more external principal caudal rays. 
ventral contour between the cleithrum and the pelvic girdle, but some elements of this series are lost because of the taphonomic events.

There are 3 pelvic scales associated with the pelvic bones and 2 postcloacal scales are located just before the postcoelomic bone.

There are flank scales only in the abdominal region of the body, anterior to the origin of the dorsal and anal fins. In the ventralmost area of the situs viscerum, between the cleithrum and the postcoelomic bone, the scales are complete, thick, deep, broad, slightly ornamented with small tubercules and articulated together. There are 11 rows of these large ventral flank scales. The other body scales are reduced to scale bars. In the dorsal area of the abdominal region the scale bars are badly preserved and only fragments are visible between the neural spines. Scale bars also are associated with the first eight dorsal ridge scales. The scales linked to the eleven other dorsal ridge scales are progressively broader and longer.

The first scale of the lateral line is visible beneath the brush-like process of the parietal.

\section{Discussion}

\section{Rhinopycnodus within Pycnodontomorpha}

We follow hereafter the most detailed phylogeny of the Pycnodontomorpha provided until now (PoyatoAriza \& Wenz 2002: fig. 43, 2004: fig. 15, 2005: fig. 10).

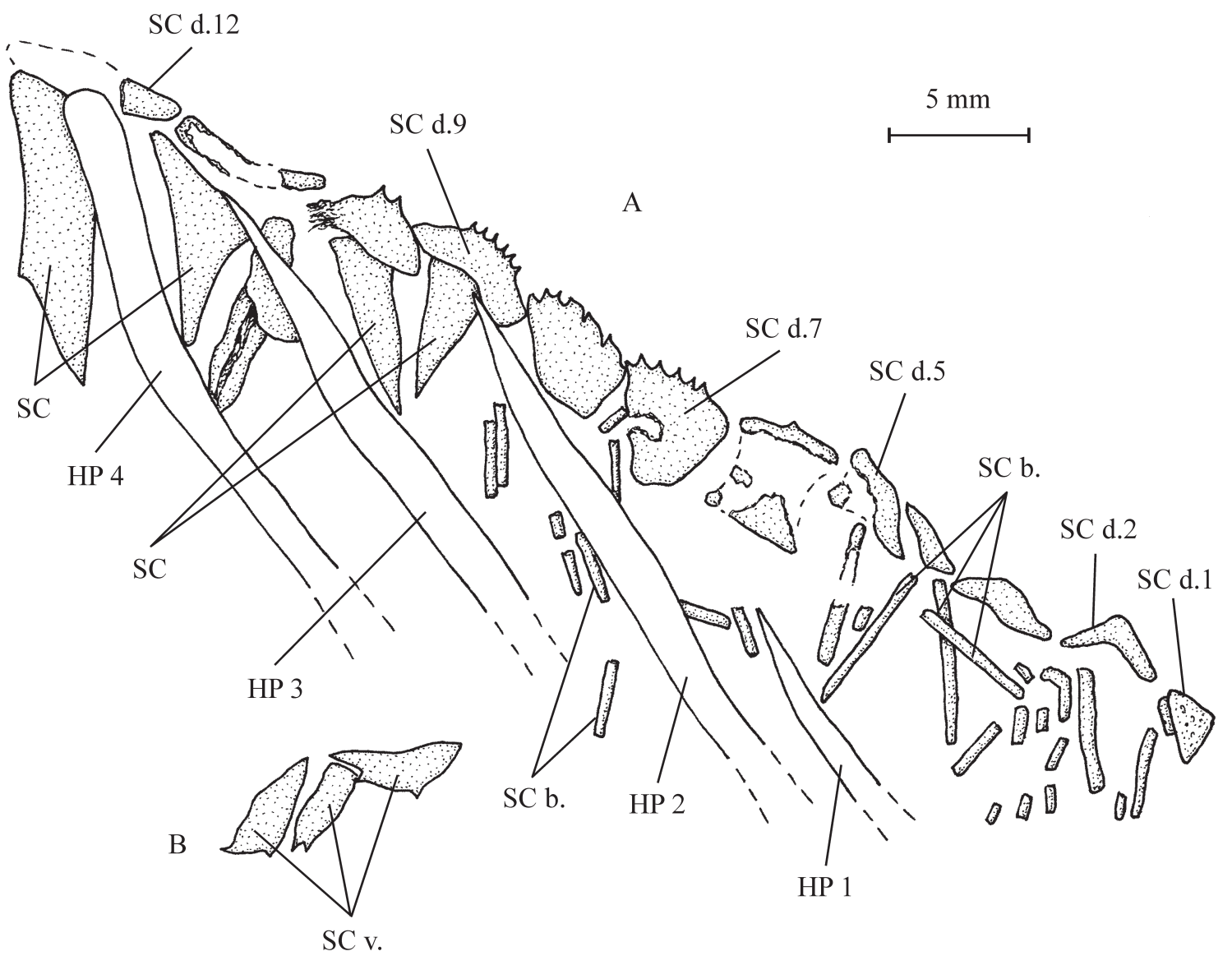

Fig. 8. Rhinopycnodus gabriellae gen. et sp. nov. A. The first twelve scales of the dorsal ridge. B. Three scales of the ventral keel. 
The presence of a brush-like process on the parietal is the principal autapomorphy of the family Pycnodontidae (Poyato-Ariza \& Wenz 2002, node 13, character 14[1]). No other member of the superorder Pycnodontomorpha has such a process. Thus, Rhinopycnodus gabriellae, with its postparietal brush-like process, undoubtedly belongs to this family.

The most primitive Pycnodontidae is Akromystax Poyato-Ariza \& Wenz, 2005, from the Cenomanian of Lebanon. It still possesses a horizontal mouth gape (Poyato-Ariza \& Wenz 2005, figs 2, 3A, B, character $5[0]$ ), a small independent supratemporal associated with the parietal (ibid. 2005, fig.6A, B, character 16[0]), a short last infraorbital (ibid. 2005: fig. 6B) and a row of complete flank scales just under the dorsal ridges scales (ibid. 2005: fig. 2). In more advanced Pycnodontidae and in Rhinopycnodus the mouth gape is oblique (ibid. 2005, node C, character 5[1]), the small supratemporal is fused to the parietal (ibid. 2005, node C, character 16[1]), the last infraorbital is elongated (Fig. 4) and there are no complete dorsal flank scales (Figs 1,2).

On the other hand, the subfamilies Pycnodontinae and Nursalliinae are the most specialized Pycnodontidae (Poyato-Ariza \& Wenz, 2002: fig. 43). In Pycnodontinae, the dermopterotic and the dermosphenotic deepen into an elongated bony pillar reaching the lower margin of the orbit, the dilatator fossa being well visible and located between the two bones (Taverne 1997: figs 2, 4; Capasso 2000: fig. 3; PoyatoAriza 2010: fig. 3). Some elements of their hypochordal series are hypertrophied (Poyato-Ariza \& Wenz 2002, node 22, character 59[2]). They have no more complete flank scales, all of them being scale bars (ibid. 2002, node 24, character 75[3]). In Nursalliinae, the frontal is curved and very broad (ibid. 2002, node 25, character 9[3]), the last neural spine before the epichordal series is vestigial (ibid. 2002, node 25, character 57[3]), some hypochordal elements are hypertrophied (ibid. 2002, node 22, character 59[2]) and the caudal fin is vertical (ibid. 2002, node 25, character 73[6]). Rhinopycnodus does not possess these apomorphies and, in consequence, does not belong to either of these two subfamilies.

The systematic position of Rhinopycnodus within Pycnodontidae is thus to be found in an intermediate subgroup situated between those two extremes.

The three most primitive genera within this subgroup are Stemmatodus Heckel, 1854 from the Early Cretaceous of Italy, Stenamara Poyato-Ariza \& Wenz, 2000 from the Early Cretaceous of Spain and Turbomesodon Poyato-Ariza \& Wenz, 2004 from the Late Jurassic and the Early Cretaceous of Europe (Poyato-Ariza \& Wenz 2004: fig. 15, 2005: fig. 10). They have the cloaca largely separated from the anal fin, with numerous ventral keel scales intercalated between these two structures and more than two poscloacal scales (Poyato-Ariza \& Wenz 2000: fig. 4, 2002: fig. 41D, 2004: figs 12, 14). Their hypochordal elements are only slightly enlarged (Nursall 1999: fig. 10B; Poyato-Ariza \& Wenz 2000: fig. 3, 2002: fig. 24, 2004: fig. 3). In Rhinopycnodus and the more evolved genera of the subgroup, the distance between the cloaca and the anal fin is shortened, with a strongly reduced number of ventral keel scales between them and no more than two postcloacal scales (Fig. 4). Some of their hypochordal pieces are markedly enlarged and plate-like (Fig. 7).

Ocloedus Poyato-Ariza \& Wenz, 2002 from the Early Cretaceous of Spain is the least specialized member among the remaining genera of the subgroup (Poyato-Ariza \& Wenz, 2004: fig. 15, 2005: fig. 10). Ocloedus possesses spines on the dorsal ridge scales (Kriwet et al. 1999: 46). Rhinopycnodus has at least some dorsal ridge scales ornamented with small spines (Fig. 8). The presence of spiny dorsal ridge scales is the primitive condition within Pycnodontidae (Poyato-Ariza \& Wenz 2002, node 16, character 92[2]). Tepexichthys Applegate, 1992 from the Early Cretaceous of Mexico, Proscinetes Gistl, 1848 from the Late Jurassic of Germany, Neoproscinetes De Figueiredo \& Da Silva Santos, 1987 from the Early Cretaceous of Brazil, Iemanja Wenz, 1989 also from the Early Cretaceous of Brazil and Coelodus 
TAVERNE L. \& CAPASSO L., A new pycnodontiform fish from the Cretaceous of Lebanon

Heckel, 1854 from the Late Cretaceous of Slovenia share a new apomorphic character. Their dorsal ridge scales have lost the spines (ibid. 2002, node 19, character (90[0]).

Thus, Rhinopycnodus occupies an intermediate position between Ocloedus and Tepexichthys in the phylogeny of Pycnodontidae.

\section{The generic validity of Rhinopycnodus}

Rhinopycnodus exhibits a broadened premaxilla bearing a single very broad tooth. No other Pycnodontidae has a premaxilla such as the one of this new Lebanese fish. Akromystax also possesses an enlarged premaxilla. However, the ventral part of the bone is plate-like and bears four rows of small molariform teeth (Poyato-Ariza \& Wenz 2005: fig. 7A), a condition quite different from that of Rhinopycnodus. Moreover, many characters of Akromystax are less advanced than in Rhinopycnodus. Polazzodus Poyato-Ariza, 2010, from the Turonian-Santonian of northern Italy, has one broad tooth on the premaxilla but the bone is narrow except in its most ventral part (Poyato-Ariza 2010: fig. 5B) and this genus belongs to the Pycnodontinae, a subfamily that is more specialized than Rhinopycnodus.

Thus, the premaxillary morphology of Rhinopycnodus is unique among the Pycnodontidae. This character is enough to confirm the peculiar generic status of the Lebanese fish.

\section{Acknowledgements}

We warmly thank Dr. Andrea Pessina, Superintendant of the Soprintendenza per i Beni Archeologici dell'Abruzzo - Chieti, for allowing us to study the fossil fishes of the Luigi Capasso's collection. We are grateful to M. Luciano Lullo from the University of Chieti and to M. Hugo De Potter from the Royal Institute of Natural Sciences of Belgium for their technical help. We also thank the anonymous colleagues who have accepted to review our manuscript.

\section{References}

Capasso L. 2000. Tergestinia sorbinii gen. nov., sp. nov. del Paleocene inferiore di Trebiciano, Trieste (Pisces, Pycnodontiformes). Atti del Museo Civico di Storia Naturale di Trieste 48: 261-289.

Kriwet J. 2001. Palaeobiogeography of pycnodontiform fishes (Actinopterygii, Neopterygii). In: Melendez G., Herrera Z., Delvene G. \& Azanza B. (eds) Los Fósiles y la Paleogeographia: 121-130. XII Jornadas de la Sociedad Española de Paleontologia, Zaragoza.

Kriwet J. 2005. A comprehensive study of the skull and dentition of pycnodont fishes. Zitteliana A45: 135-188.

Kriwet J, Poyato-Ariza F.J. \& Wenz S. 1999. A revision of the pycnodont fish Coelodus subdiscus Wenz, 1989, from the Early Cretaceous of Montsec (Lleida, Spain). Treballs del Museu de Geologia de Barcelona 8: 33-65.

Nursall J.R. 1996a. Distribution and ecology of pycnodont fishes. In: Arratia G. \& Viohl G. (eds) Mesozoic Fishes - Systematics and Paleoecology: 115-124. Verlag Dr. F. Pfeil, München.

Nursall J.R. 1996b. The phylogeny of pycnodont fishes. In: Arratia G. \& Viohl G. (eds) Mesozoic Fishes - Systematics and Paleoecology: 125-152. Verlag Dr. F. Pfeil, München.

Nursall J.R. 1999. The pycnodontiform bauplan: The morphology of a successful taxon. In: Arratia G. \& Schultze H.-P. (eds) Mesozoic Fishes - Systematics and Fossil Record: 180-214. Verlag Dr. F. Pfeil, München. 
Nursall J.R. 2010. The case for pycnodont fishes as the fossil sister-group of teleosts. In: Nelson J. S., Schultze H.-P. \& Wilson M.V.H. (eds) Origin and Phylogenetic Interrelationships of Teleosts: 37-60. Verlag Dr. F. Pfeil, München.

Poyato-Ariza F.J. 2010. Polazzodus, gen. nov., a new pycnodont fish from the Late Cretaceous of northeastern Italy. Journal of Vertebrate Paleontology 30 (3): 650-664. http://dx.doi.org/10.1080/ $\underline{02724631003762955}$

Poyato-Ariza F.J. \& Wenz S. 2000. A new pycnodontiform fish from the eraly Cretaceous of Las Hoyas (Cuenca, Spain). Bulletin de la Société géologique de France 171 (3): 251-258.

Poyato-Ariza F.J. \& Wenz S. 2002. A new insight into pycnodontiform fishes. Geodiversitas 24 (1): 139-248.

Poyato-Ariza F.J. \& Wenz S. 2004. The new pycnodontid fish genus Turbomesodon, and a revision of Macromesodon based on new material from the Lower Cretaceous of Las Hoyas, Cuenca, Spain. In: Arratia G. \& Tintori A. (eds) Mesozoic Fishes 3 - Systematics, Paleoenvironments and Biodiversity: 341-378. Verlag Dr. F. Pfeil, München.

Poyato-Ariza F.J. \& Wenz S. 2005. Akromystax tilmachiton gen. et sp. nov., a new pycnodontid fish from the Lebanese Late Cretaceous of Haqel and En Nammoura. Journal of Vertebrate Paleontology 25 (1): 27-45. http://dx.doi.org/10.1671/0272-4634(2005)025[0027:ATGESN]2.0.CO;2

Taverne L. 1997. Les poissons crétacés de Nardò. $5^{\circ}$. Pycnodus nardoensis sp. nov. et considérations sur l'ostéologie du genre Pycnodus (Actinopterygii, Halecostomi, Pycnodontiformes). Bollettino del Museo di Storia Naturale di Verona 21: 437-454.

Manuscript received: 6 March 2013

Manuscript accepted: 8 November 2013

Published on: 4 December 2013

Topic editor: Christian de Muizon

Desk editor: Kristiaan Hoedemakers

Printed versions of all papers are also deposited in the libraries of the institutes that are members of the EJT consortium: Muséum National d'Histoire Naturelle, Paris, France; National Botanic Garden of Belgium, Meise, Belgium; Royal Museum for Central Africa, Tervuren, Belgium; Natural History Museum, London, United Kingdom; Royal Belgian Institute of Natural Sciences, Brussels, Belgium; Natural History Museum of Denmark, Copenhagen, Denmark. 